\title{
Erken Ortaçağ Balkan Hâkimiyetinde Bulgar-Bizans Savaşları: Gümüş Kaplama Kuru Kafalar ve Kör Ordular
}

\section{The Bulgarian-Byzantine Wars for Early Medieval Balkan Hegemony: Silver-Lined Skulls and Blinded Armies}

Dennis P. Hupchick, The Bulgarian-Byzantine Wars for Early Medieval Balkan Hegemony: Silver-Lined Skulls and Blinded Armies, Pennsylvania: Palgrave Macmillan 2017, 348 sayfa, ISBN 978-3-319-56205-6

\section{Esra KızIl 10}

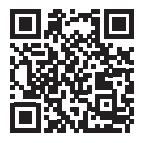

'Sorumlu yazar/Corresponding author: Esra Kızl (Arş. Gör.), Yozgat Bozok Üniversitesi, Fen-Edebiyat Fakültesi, Tarih Bölümü, Yozgat, Türkiye.

E-posta: esra.kizil@yobu.edu.tr ORCID: 0000-0003-1945-3352

Başvuru/Submitted: 09.05.2021

Kabul/Accepted: 09.05.202

Atıf/Citation: Kizil, Esra, "The BulgarianByzantine Wars for Early Medieval Balkan Hegemony: Silver-Lined Skulls and Blinded Armies" (Kitabiyat). Güney-Doğu Avrupa Araştırmaları Dergisi, 36 (2021), s. 135-144 https://doi.org/10.26650/gaad.361351
Anahtar Kelimeler: Bulgarlar, Bizans İmparatorluğu, Balkan Hâkimiyeti, Krum, Simeon

Keywords: Bulgarians, Byzantine Empire, Balkan Domination, Krum, Symeon 
Eser; önsöz (s. VII-XI), şekil ve haritaların listesi (s. XVII), metin içerisinde yer alan bazı kelimelerin yazım ve telaffuz biçimleri (XIX-XX), Bulgarlar ve Bizans arasında geçen hâkimiyet savaşlarının kronolojik sıralaması (XXI-XXXI), kısaltmalar (XXXIII-XXXV) ve giriş kısmı dâhil olmak üzere toplam sekiz bölümden oluşmaktadır. Zengin bir bibliyografyanın yer aldığı çalışmada farklı dillerde yayımlanmış araştırmalardan faydalanılmış olması dikkat çekmektedir. Önsözde belirtildiği üzere yazar bu kitap ile okurlara, erken Ortaçağ döneminde Balkan Yarımadası'nın hâkimiyeti için Bulgarlar ve Bizans İmparatorluğu arasında geçen muhârebeler hakkında değerlendirmeler sunmaktadır. Nitekim müellif, IX. yüzyılın başından XI. yüzyılın başlarına kadar geçen sürede Ortaçağ Avrupa'sının Ortodoks dünyasında verilen hâkimiyet mücâdelesinde Bulgarların önemli bir rol oynadığını düşünmüş ve yaklaşık 200 yıla yayılan Bulgar-Bizans savaşlarına, İngilizce kaleme alınmış Ortaçağ Avrupa askerî tarihi kaynaklarında çok az yer verildiğini dile getirmiştir. Batı Avrupa medeniyetinin kültürel alanının dışında kalmaları, İngiliz diline hâkim Bulgar veyâhut Bizans tarihi uzmanlarının çoğunun daha genel bir okuyucu kitlesinden ziyâde belli bir kesime yönelik çalışmalar üretmiş olması ve erken Ortaçağ Bulgar tarihi alanında İngilizce lisanına vâkıf tarihçilerin azlığı yazar tarafından bu durumun sebepleri olarak görülmektedir. Bununla birlikte mezkûr alandaki eksikliği tamamlamak adına Bulgar tarihçilerin kapsamlı araştırmalarından yararlanılmış ve dokümanlar mevcut İngilizce çalışmalar ile bütünleştirilerek, Bulgarlar ve Bizans arasında geçen erken Ortaçağ savaşlarının detayları müellifin kaleminden aktarılmıştır. Ana vurgunun askerî faâliyetler olduğu eserde, konuyla bağlantılı olarak önemli görülen siyasî, kültürel ve iktisâdî konular da ele alınmıştır. Yazar, Ortaçağ Avrupa'sının en etkili, düzenli ve eğitimli kara ordusu gücüne sahip olan Bizans'ın askerî örgütlenmesi ve taktiklerine eserinde yer verilmemesine sebep olarak Warren Treadgold, John Haldon gibi uzmanların son zamanlarda bu konuda çalışmalar hazırlamış olmalarını göstermekte ve aynı bilgilerinin tekrarlanmasına ihtiyaç duyulmadığını belirtmektedir. Nitekim müellifin çalışmasında odaklandığı esas nokta Bizans'tan çok Bulgarlar olmuştur.

Muhârip Devletler isimli giriş kısmı (s. 1-36) aynı zamanda yazar tarafından birinci bölüm olarak sunulmuş ve Bizanslılar, Bulgarlar, müttefik kuvvetler, silâhlanma, tahkîmat ve savaş taktikleri alt başlıklar hâlinde genel hatlarıyla anlatılmıştır. Bununla birlikte yaklaşık 200 yıl boyunca süren Bulgar-Bizans savaşlarının seyrini etkileyen belli başlı özelliklere değinilmiştir. Diğer yandan hâkimiyet mücâdelesinde Balkan Yarımadası'nın, Bulgarlar ve Bizans İmparatorluğu için çekişme noktası hâline geldiği belirtilerek Balkanların stratejik önemi yansıtılmaya çalışılmış ve IX. yüzyıla kadar olan sürecin değerlendirilmesi yapılarak, her iki devletin genel durumuna temas edilmiştir. Bizans'ın oluşturduğu Thema Sistemi ile ordunun ve idârenin geçirdiği dönüşüm aktarılırken, Bulgarların ise IX. yüzyılın başlarına kadar bir devlete sahip olmadığı ve yarı göçebe yaşayan bir topluluk olduğunun vurgusu yapılmıştır. Hem Bizans İmparatorluğu'nun hem de Bulgarların idârî ve askerî sistemindeki benzer ve farklı yönlerinin ayrıntılı bir şekilde ele alınması ise mücâdelelerin muhâkeme edilmesi açısından 
önemli olmuştur. Yazar, "Bulgar" toplumunun oluşum aşamasında, Kiril Slav dilini benimsemeleri ve Ortodoks Hıristiyanlığı'nı kabul etmelerini Bulgar-Slav kaynaşmasıyla irtibatlandırırken, Slavlarla birleşerek demografik açıdan nüfuz elde eden Bulgarların hızla genişlemesi ve Bizans'ın bu duruma engel olmaya çalışmasını mücâdelelerin temel sebebi olarak yorumlanmıştır. Ayrıca bu bölümde, Bulgar-Bizans hâkimiyet mücâdelelerinin seyrine önemli etkiler sağladığını düşündüğü müttefik kuvvetler, alt başlık olarak değerlendirilmiş olup; Macarlar, Peçenekler, Hırvatlar, Sırplar ve Kiev Ruslarının tarihî menşei, demografik, idârî yapıları ve kültürel özelliklerinden bahsedilmiştir. Müellif bu bölümün son kısmında, savaşların tarihsel anlatısını ilginç kılan, çatışmaların seyrinde belirleyici olan silâhlanma, tahkîmat ve taktiklerden bahsetmiştir. Mücâdelelerin seyrini, liderlerin potansiyeli, genel niyet, arazi yapısı ve düşmanların yeteneklerinin belirlediği vurgulanırken, aynı zamanda bu mücâdelelerdeki genel üstünlüğü görebilmek adına hem Bulgar hem de Bizans askerî birliklerin kullandıkları silâhlar, muhârebe kıyâfetleri, savunma sistemi, uygulanan taktik ve stratejilerin genel özelliklerinden bahsedilerek okuyucunun karşılaştırma yapması hedeflenmiştir. VII. yüzyıldan XI. yüzyııın başlarına kadar uzanan taktik ve strateji hakkında günümüze kadar gelen Bizans çalısmalarının, Bizans'ın savaş stratejisine ve kullandığı teknolojiye yönelik yaklaşımı hususunda zengin bilgi sağladığl; Bulgarlar hakkında bilinenlerin ise büyük ölçüde mevcut Bizans kaynaklarında net olmayan eski tarz anlatımlardan elde edildiği de dile getirilmiştir.

Çalışmanın 679'dan 803'e Kadar Bulgar Devleti'nin Teşekkülü ve Bekası isimli ikinci bölümünde (s. 47-64) Bulgar Devleti'nin kuruluş sürecine ve dönemin Bizans İmparatorları ile olan askerî ve diplomatik ilişkilerine yer verilmiştir. Bizans İmparatorluğu'nun genel idârî, askerî ve kültürel yapısının yanında, Doğu'da Araplar ve Perslerle, Batı'da ise Slavlar ve Avarlarla verdiği mücâdelelerden bahsedilmiştir. Bizans'ın içeride ve dışarıda sahip olduğu konum hakkında detaylı bilgiler verilmesi, Bulgarların bölgede kolaylıkla nasıl hâkimiyet kurabildiğinin görülmesi açısından önem arz etmektedir. 717 yılına gelindiğinde, karşsıklı çıkarlar doğrultusunda ilerleyen Bulgar-Bizans münâsebetlerinde savaş yerini önemli bir ittifaka bırakmıştır. Bulgarların yardımıyla İstanbul'da Müslüman Araplara karşı kazanılan zafer, Bulgar Devleti için bir dönüm noktası olarak görülmüş ve Bulgarların Avrupa'nın önemli bir gücü hâline geldiği şeklinde yorumlanmıştır. Hem Türk hem de Bizans geleneklerinden faydalanan Bulgar Devleti'nin idârî ve kültürel yapısından bahsedilmiş, ancak 720'lerden 750'lere kadar yaşanan iç gelişmeler hakkında çok az şey biliniyor olması ise dönemin ana kaynaklarının eksikliğine bağlanmıştır. Çalışmada Bulgar-Bizans mücâdelelerinin asıl sebepleri üzerine yapılan çeşitli değerlendirmelere de yer verilmiştir. Müellifin bu konudaki görüşü, V. Konstantin'in (741-775) seferleri çoğu kez Bulgar Devleti'ni yok etmeye yönelik bilinçli çabalar olarak nitelendirilse de imparatorluk bölgelerinin nüfusunu muhâfaza etmek ve artırmakla ilgilidir. Bulgar kaynaklarının eksikliği ise VIII. yüzyılda Bulgarlar arasındaki bölünmenin gerçek sebeplerini ve sosyo-politik boyutlarını ayırt edilemez hâle getirmiş, ayrıca ortaya çıkan olgusal boşluğun iç ve dış nedenlere dayalı olarak farklı hipotezlerle doldurulmasına sebep olmuştur. Yazar öne 
sürülen iddiaların kaynaklarda bulunan bilgilerle çeliştiğini ve bu nedenle geleneksel varsayımlara eleştirel şüphe ile bakııması gerektiğini vurgulamıştır. Var olan kaynakların ışığında, VIII. yüzyılda yaşanan siyasî krizin muhtemel sebepleri sunulmuş ve idârî bölünmede öne sürülen teorilerin dışında nedenlerin çok yönlü olduğu hususu belirtilmiştir.

Eserin 809'dan 814'e Kadar Krum'un Sınırları Genişletme Seferleri isimli üçüncü bölümünde (s. 67-114), verilen tarih aralığında yer alan Bulgar-Bizans savaşlarından ve genişleme politikalarından bahsedilmiştir. Bizans İmparatorluğu'nun Balkanlardaki ilerlemesinin durması ordudaki disiplinsizliğe ve itâatsizliğe bağlanırken, buna karşın başarılı bir hükümdarın iç otoriteyi sağladığı Bulgar Devleti'nde askerî başarıların bölgesel genişlemeyi başlattığının düşünülmesi bu bölümde dikkat çekmektedir. Böylece Bizans ordusunun kusurlarının yanı sıra, Bulgar başarılarının ve zaferlerinin Bulgar hükümdarlarının kişiliklerine, onların askerî ve politik becerilerine de dayandığı anlatılmak istenmiştir. IX. yüzyılın başlarında ise Bulgarların Balkanlarda hâkimiyet alanını genişletmesine karşın, Bizans'ın sınırlarını korumak ve imparatorluk otoritesini yeniden sağlamak üzerine aldığı bir dizi önlem üzerinde durulmuştur. Bizans İmparatorluğu'na karşı verilen mücâdelelerde kazanılan başarılarla Bulgar Devleti'nin (803-814) yükselişini başlatan hükümdar Krum Han'ın etnik kökeninin nereye dayandığı konusunda çeşitli iddiaların varlı̆ına ve de Bizans'ın yaptığı sosyo-ekonomik reformlar, thema ordusunu genişletme çabasının yanı sıra demografik üstünlüğü sağlayabilmek adına Anadolu'dan Balkanlara gerçekleştirdiği göç hareketine dikkat çekilmiştir. 809 ve 811 yılları arasındaki dönemde Bulgar Devleti'ndeki gelişmelerin ayrıntılarının eksik olması ise kaynak yetersizliğine bağlanmıştır. Buna rağmen yazar, Krum Han'ın hükümdarlı̆ı devrindeki faâliyetleri güçlü merkezi devlet otoritesini yaratmaya çalışmak olarak tahayyül etmektedir. Nitekim bu noktada Bulgarların gücünü artırmak adına, Bizans'ın imparatorluk birliklerine karşı Avarlar ve Slavlarla olan ittifakı ele alınmıştır. Bizans'ın askerî gücüne mukavemet edebilecek bir hükümdar olarak görülen Krum Han savaş sonrası meşrûiyetini ve askerî gücünü artırmaya çalışırken; Bizans tahtının yeni sahibi I. Mikhail (811-813) ise hükümdar olarak kabulünü pekiştirmek ve imparatorluğu yeniden inşa etmek için mücâdele etmek zorunda kalmıştır. 813 yılında gerçekleşecek olan Versinikia Muhârebesi'nin Bulgarların lehine sonuçlanması ise Bizans ordusunun disiplinsizliğine mâl edilmiştir. Yazar, başarısızıkta etkisi olduğunu düşündüğü I. Mikhail'i komutandan çok seyirci olarak nitelendirmiş ve savaştaki isteksizliğinin nedenini farklı varsayımlara dayandırmıştır. Versinikia Savaşı'yla ilgili çoğu çalışmada Krum Han'ın sayıca üstün olan Bizans'a karşı galip gelebilmesinin tek olası sebebi olarak Ermeni Leon ve kumandanlarının ihâneti olarak ifâde edilmişse de yazar, I. Mikhail'ın beceriksiz liderliğini mağlûbiyetin temel nedeni olarak gördüğünü belirtmiştir. Yazar Bulgar zaferlerinin sebebini Bizans komutasının bölünmüş ve disiplinsiz oluşuna dayandırmaktan ziyâde asıl üzerinde durulması gereken hususun Bulgar hükümdarlarının askerî ve politik becerileri olduğunu belirtmiştir. Meşrûiyetini sağlamlaştırmak adına boy liderleri ve müttefikleriyle olan münâsebetlerinin de ele alınması, hâkimiyetin genişlemesine etki eden diğer nedenleri gör- 
mek açısından ehemmiyet arz etmektedir. 815 yılında Omurtag'ın (814/815-831), İmparator V. Leon'a (813-820) karşı kaybettiği savaşın sonunda ise uzun yıllar sürecek barış ortamı sağlanmıştır. Yaklaşık 40 yıl sürecek barışın vukû bulmasıyla genç ve tecrübesiz olarak nitelendirilen Omurtag'ın liderlik otoritesini tekrar istikrâra kavuşturmak amacı ilişkilendirilmiş ve Omurtag'ın antlaşma maddelerini yazdırdığı mermer sütundan günümüze kadar ulaşabilen kalıntıları üzerinden bir değerlendirmeye gidilmiştir.

Çalışmanın Bulgar Devleti'nden Bulgaristan'a, 816-893 başlıklı dördüncü bölümünde (s. 123-143) uzun yıllar sürecek barış döneminde Bulgarların ve Bizans'ın karşı karşıya kaldığı hem iç hem de dış meseleler üzerinde durulmuştur. Karşılıklı çıkar ilişkilerinin ortaya çıktığı bu dönemde Bizans taht mücâdelesinde Bulgarlarla yapılan ittifakın yanı sıra, Slavların, Bulgarlara karşı Franklarla irtibata geçtiğine değinilmiştir. 824 yılında Omurtag, Franklarla sınır ve demografik sorunların çözümü amacıyla diplomatik temasa geçmeye çalışmış ancak girişimi sonuçsuz kalınca 834 yılına kadar sürecek bir savaş başlamıştır. Sınırların güvenliğinin sağlanmasıyla birlikte iç işlerdeki düzenin oluşturulması Omurtag'ın devlet idâresini merkezî bir yapıya dönüştürmesi olarak yorumlanmıştır. Barış döneminde bile iki devletin zaman zaman Makedonya sorunu ve Slavlarla ilgili meselelerde karşı karşıya geldiğinden bahsedilmiş olması asıl amaçlarının görülmesi açısından önemli olmuştur. Ayrıca 836'dan 852'ye kadar hüküm süren Bulgar Hanı Presiyan tarafından dikilen bir sütun üzerinde yer alan ifâdelere yer verilmesi hâlen Bizans'a karşı duyulan güvensizliği ortaya koymaktadır. Var olan kaynaklara göre, Presiyan'ın yayılmacı siyaset izlediğinin ayrıntıları belirsiz olmasına rağmen, yazar Bulgar genişlemesinin gerçekleştiği coğrafyalara eserinde yer vermiştir. Bulgarların batıya genişlemesini engelleyecek olan 839-842 yılları arasındaki Sırp-Bulgar mücâdelesi ve Bizans'ın bu mücâdeledeki tutumu üzerinde durulmuştur. IX. yüzyılın ortalarında Bulgar Devleti'nin ve Bizans İmparatorluğu'nun Balkanlarda sahip oldukları toprakların sınırları belirtilmiştir. Balkanların coğrafi yapısının merkezi yönetim biçimine olumsuz etkisinin yanı sıra devletin geniş hâkimiyet alanı içerisinde yaşayan halkın kültürel bölünmüşlüğü gösterilmeye çalışılmıştır. Bu dönemde Bizans'ın, Bulgarların hâkimiyetini kırabilmek için çeşitli ittifak girişimlerinden ve buna karşılık Franklar yanında Almanlarla sınır güvenliğini sağlayacak diplomatik ilişkileri başlatmasından da söz edilmiştir. Yazar, I. Boris'in (852-889), dış münâsebetler için fayda sağlayabileceğini düşünerek Hıristiyanlığa geçmek istediğinden dolayı Franklarla ittifak kurduğuna ancak sağlayacağı kazancın yanında kültürel kayıpların neler olabileceği hususuna temas etmiştir. Bizans İmparatorluğu'nun Balkanlarda papalık otoritesinin genişlemesine ve Frankların Balkan Yarımadası'ndaki nüfuzunu engelleyebilmek adına Bulgarları yanına çekme girişimine dikkat çekilmiş ve Bulgar-Bizans görüşmelerine müteâkip I. Boris'in Hıristiyanlığı kabul etmesinin Bulgarlar üzerindeki etkisi değerlendirilmiştir. Kitlesel ölçekte din değiştirmenin doğurduğu kültürel dönüşüm yerleşik pagan değerlerini, âyinlerini ve geleneklerini değiştirmiş ve bu durum Bulgar liderler için asimilasyon olarak tanımlanmıştır. Kültürel değişimi ka- 
bullenmeyen halkın isyan girişimlerinden ve I. Boris'in otoritesini güçlendirmek için aldığı önlemler üzerinde durulması, yeni bir dinin kabul edilmesiyle ortaya çıkabilecek sorunları görmek açısından önemlidir. I. Boris, 865 yılında Bulgar Devleti'nin siyasî bağımsızlığını garanti altına alabilmek adına bağımsız bir kilise kurma girişiminde bulunmuş ve bunun üzerine hem Bizans Ortodoks Kilisesi hem de Katolik Kilisesi ile olan irtibatı ele alınmıştır. 870 'te ise Bulgar Kilisesi, Ortodoks Patrikhânesi'ne bağlı özerkliğini kazanmasından sonra vukû bulan misyonerlik faâliyetlerine değinilmiştir. Bu bölümde ayrıca Hıristiyanlığın kabulü ile devletin idârî yapısındaki dönüşüm ve meydana gelen din, dil ve kültürel değişiklere de dikkat çekilmiştir.

Müellif, 894'ten 927'ye Kadar Imparatorluk Tasdiki lçin Simeon'un Seferleri adını verdiği eserin beşinci bölümünde (s. 149-210) Hıristiyanlığı yeni kabul eden Bulgar Devleti'nin, Bizans İmparatorluğu'ndaki dînî ve siyasî konumu üzerinde durmuştur. Uzun süredir Balkanların hâkimiyetini engelleyen tehlikeli pagan düşman, artık Bizans'ın Balkanlardaki kültürel ve politik koruyucusu olarak tanımlanmıştır. En güçlü Ortaçağ Bulgar hükümdarı olarak tanımlanan Simeon'un (893-927) iç ve diş meselelerdeki muvaffakiyetinden bahsedilmiştir. Nitekim yazar, Bulgaristan'ın "Altın Çağı" olarak tasvir edildiği Simeon'un hükümdarlık dönemini haritayla îzah etmiştir (s. 152). Bizans ile iyi giden ilişkilerin bir ticaret anlaşmazlığı ile bozulmasının nedenleri ise farklı teorilere dayandırılarak verilmiştir. Bununla birlikte Simeon'un Bizans karşııı tutumu hâkimiyetini kabul ettirme çabası olarak yorumlanmıştır. Müellif bazı Bizans kaynaklarının, Bulgar zaferiyle netîcelenen mücâdelelerde Bizans askerî ve diplomatik eylemlerinin başarısızlığının bilerek görmezden gelindiğini iddia etmektedir. Simeon'un döneminde başkent Preslav'ın Bulgaristan'da daha önce hiç tanık olunmayan, Slav-Ortodoks kültür ve ticaret merkezine dönüşümü hakkında tafsîlâtlı bilgiler bulunmaktadır. X. yüzyılın ilk yılları barış zamanı olarak tasvir edilse de bazı kaynaklarda yer alan mâlûmata göre; Bulgarların güneybatı sınırında hâkimiyetini genişletmek amacıyla imparatorluğa karşı sınırlı sayıda askerî eylemlerde bulunduğu bilgisi verilmiştir. Bizans'ın Balkan hâkimiyetine yoğunlaşması Doğu'da Araplarla oluşacak meseleyi gün yüzüne çıkarmış ve bu nedenle Bizans'ın doğuya yönelmiş olması, Bulgaristan'ın topraklarını genişletmesini kolaylaştırması olarak tefsir edilmiştir. Bazı araştırmacılar tarafından 913 yılından sonra Simeon'un yazışmalarda çar ya da imparator unvanlarını resmî olarak kullanmaya başlaması ve taç giymesi, Bizans imparatorluk tahtını elde etmeyi düşündüğü şeklinde yorumlanmıştır. Ancak Bizans'ta muhâlif güçlerin hâkimiyeti ele geçirmesiyle Simeon'un statüsü tanınmamış ve sonrasında bozulan Bulgar-Bizans münâsebetlerindeki durum değerlendirilmiştir. Mücâdelelerin Bulgarların zaferiyle netîcelenmesi ve Bizans başarısızlığının sebepleri özellikle Peçeneklerin Bizans aleyhindeki tutumları kullanılan kaynaklar ekseninde temellendirilmeye çalışılmıştır. Yazar, 917 yılında vukû bulan Achelous Muhârebesi'ni Simeon'un en büyük askerî başarısı olarak tanımlarken, Bizans için ise imparatorluğun yaşadığı en kötü felâketlerden birisi olarak tasvir etmiştir. Savaşı kazandıran Bulgar birliklerinin son derece eğitimli ve disiplinli savaşçılar olduğundan bahsedilirken, askerî 
üstünlük sağlayan Simeon'un, imparatorluğunu meşrûlaştırılmak amacıyla gerçekleştirdiği diplomatik girişimler ve Balkanlardaki hâkimiyet mücâdelesi ele alınmıştır. 924 yılında Bizans ile yapılan antlaşma ateşkes olarak nitelendirilmiş ve müzâkerede görüşülen konuların belirsizliğini koruduğu ifâde edilmiştir. Yazar hâdiseyi ihtivâ eden Bizans kaynaklarının efsanelerle işlenmiş olduğu ve kendileri için mâkul olacak şekilde bilinçli bir çabayla aktarıldığı düşüncesindedir. Görüşmelerin sonunda Simeon'a, Bizans İmparatoru ile eşit imparatorluk statüsü verilse dahi çeşitli iddiaların varlığına dikkat çekilmiştir. Uzun süren askerî ve diplomatik çabaları sonuç veren Simeon'un imparatorluk konumunun uluslararası tanınırlığa sahip olduğunun vurgulanması, elde edilen zaferin önemini göstermesi bakımından önemli olmuştur.

Eserin 971 yılından 971 'e Kadar Ihtiyatlı Barıştan Rus Müdahalesine adlı altıncı bölümünde (s. 221-242) Bulgar Devleti'nin verâset durumdan kaynaklı iç meselelerin yanı sıra isyanlar, Bizansla değişen ilişkiler, Sırbistan'ın kaybı, Macar ve Peçenek baskını gibi konular ele alınmıştır. 927 yılında tahta geçen I. Peter'in, hükümdarlık konumunu sağlamlaştırmak ve komşu devletlere gücünü kanıtlamak amacıyla giriştiği Bizans mücâdelelerinden bahsedilmiştir. Yaşanan ihtilâfların sonunu getiren sebepler ve sınırlar, esirler, imparatorluk unvanın tanınması gibi meselelerin yer aldığı ateşkesin ayrıntılarına geniş bir şekilde yer verilmiştir. Sırasıyla Bizans İmparatoru I. Romanos'un (920-944) torunuyla I. Peter'in diplomatik evliliğinin ve Bulgar Patrikhâne'sinin resmî olarak kabul edilmesinden sonraki Bulgar-Bizans münâsebetlerinin seyrine değinilmiştir. Yazar bu sürece âit belgelerin yetersizliğine dikkat çekerken, tarihçilerin Bulgaristan'ı, askerî, idârî ve kültürel problemlerin içinde gerilemekte olan bir devlet olarak tasvir ettiklerini dile getirmiştir." Gerilemeye dâir ortaya atılan varsayımların doğruluğu yazar tarafından sorgulanmış ve I. Peter'in hükümdarlığı sırasında devletin mevcut servetinin arttığını destekleyen arkeolojik bulgulara yer verilmiştir. Yeni dönem tarihçilerinin, bulgulara göre gerileme dönemi hipotezlerinin çürüdüğü ve aslında Bulgar Devleti'nin altın çağını yaşayan güçlü bir devlet olarak tahayyül edilebileceği hususu vurgulanmıştır. Modern tarihsel ve antropolojik araştırmalara göre, demografik üstünlüğe sahip olan köylülerin Hıristiyanlığa rağmen eski gelenek ve âyinlerinden vazgeçememe durumu da ele alınmıştır. Köylünün toplumsal hoşnutsuzluğunu ifâde eden bir kitle hareketi olarak kendisini gösterecek olan bu durum Bogomilizm olarak tanımlanmıştır. X. yüzyılın ikinci yarısında Balkanlarda ortaya çıkan Rus saldırılarının, her iki devlet üzerindeki etkisi incelenmiştir. 968 yılında yapılan Kiev Knezi I. Svyatoslav ile Bizans İmparatoru II. Nikephoros Phokas (963-969) arasındaki ittifakın, 970 yılında Rusların Balkan topraklarında hâkimiyet kurma çabasıyla düşmanlığa dönüşme aşaması tasvir edilmiştir. Mücâdelenin Bizans'ın lehine netîcelenmesi ile Rusların yanında yer alan Bulgarlar için yeni bir dönem başlamıştır. Bizans için sonuç, Balkan hâkimiyetinde ebedî rakibi olan Bulgaristan'ı aşağı çekmesi olarak yorumlanmıştır. Bizans İmparatorluğu'nun hâkimiyetine giren Bulgar Devleti ise imparatorluk unvanı ve dînî özerkliğini kaybetmiştir. Yazar, Bizanslıların Bulgaristan'ı rakip devlet olmaktan çıktığını varsaysalar da Bulgaristan'ın batı topraklarında yaşayanları hesaba katmadıklarını dile getirmiştir. 967 ile 971 yılları arasında 
Bulgarlar üzerine gerçekleşen Rus ve Bizans askerî faâliyetlerine dâir hiçbir kanıtın mevcut olmadığına dikkat çekilmiş ve böylece hayatta kalan lider ve savaşçıların, imparatorluğu 42 yıl daha korumayı başarabilmesi bu duruma bağlanmıştır.

Eserin 976'dan 1018'e Kadar Samuel'in Bulgar Devleti Hâkimiyet Seferleri ve Bulgar Mağlûbiyeti adını taşıyan yedinci bölümünde (s. 247-307) 960'dan 976'ya kadarki olan döneme ilişkin kaynakların yetersizliğinden dolayı Bulgar Devleti'nin statüsü üzerine sunulan hipotezlerin değerlendirilmesi yapılmıştır. IX. yüzyılın sonlarında "tipik” erken Ortaçağ Avrupa devleti olarak tanımlanan Bulgar Devleti'nin yönetim sistemi, hükümdar-soylu boyar aileler ilişkisi üzerinden îzah edilmeye çalışılmıştır. Bulgar Devleti'nin düşüşüne müteâkip, Batı'da Bizans varlığının yokluğundan faydalanan bir grup Bulgar soylusunun idârî ve askerî otoriteyi yeniden sağlama çabası üzerinde durulması, Bizans idâresine karşı verilen tepkiyi göstermektedir. Batı Bulgar topraklarının örgütlenmesi ve idâresine katkıda bulunan Nikola ve dört oğlunun etnik kökeni üzerine de değerlendirmeler yapılmıştır. Bulgar tarihçilerin bu yönetim otoritesini tetrarşi olarak tanımladığından ve kardeşlerin idâresinde olan Batı Bulgarları ile Bizans İmparatorluğu hâkimiyet mücâdelesinin detaylarından söz edilmiştir. Kardeşler arasından Samuel'i (958-1014) liderliğe yükseltecek olan, 980-1014 yılları arasındaki seferler ise bir harita ile resimlendirilmiştir. (s. 257). 986 yılındaki Bulgar-Bizans mücâdelesi ve her iki devlet açısından savaşların seyri ise tafsîlâtlı bir şekilde değerlendirilmiştir. Samuel ve II. Basileios'u (976-1025) karşı karşıya getiren 986 Trajan Boğazı Muhârebesi karakterize edilirken; seferin sonunda Samuel önderliğinde Bulgarların yeniden yükselişe geçtiği ve II. Basileios'un ordusunun ve liderliğinin zedelendiği süreç incelenmiştir. Krum Hânedanının son üyesi olarak Samuel'in, kendisini resmî olarak çar îlân etme (997-1014) kararını hem içeride soylu boyar ailelere hem de sınırlardaki Bizans müttefiklerine karşı, hükümdarlık îtibarını meşrûlaştırmak amacıyla aldığı vurgulanmıştır. Yazar, bazı modern milliyetçi akademisyenlerin Samuel'in devletinin bir “Ermeni" tarafından yönetilen bir “Makedon" İmparatorluğu olarak değerlendirmesine rağmen, milliyetçilik ve etnisite kavramlarının erken Ortaçağ Balkanları için geçerli olmadığını ve tüm işaretlerin onu Bulgar olarak gösterdiğini ifâde etmiştir. Etnik kökeni üzerine ortaya atılan iddialara anakronizm sorunu ile açıklık getirmeye çalışması, yazarın bu konudaki kendi çıkarımını güçlü kılmaktadır. Samuel'in imparatorluğunun iç işleyişi hakkında yeterli bilgi olmamasına rağmen, Bizanslı tarihçi loannes Skylitzes'in notlarının idârî, kültürel, iktisâdî ve dînî yapılanmaları hakkında bilgi sağlayan tek mevcut kanıt olduğu vurgulanmıştır. Var olan kaynaklar üzerinden, 1001-1005 yılları arasında yer alan Bulgar-Bizans askerî ve diplomatik münâsebetleri hakkında da değerlendirilmeler yapılmıştır. Yazar, 1001 ve 1014 yılları arasında geçen hâdiseleri aydınlatacak kaynakların yetersizliğine ya da taraflı yazılabilecek olmasına dikkat çekerken, II. Basileios'un 1018'de galip geldiği bir netîce elde edene kadar savaşa devam etmesindeki asıl amacını Balkanlardaki Bulgaristan'ı yok etme çabası olarak yorumlamıştır. Uzun yıllar sürecek olan ikili mücâdeleler esnasında her iki devletin de ordusunun savaştaki dizilimi, askerî stratejileri ve kullandığı silâhlar hakkında genel bilgilere yer 
verilmiştir. 1014 yılında Bulgar Çarı Samuel'in hayatını kaybetmesinden sonra otoritede vukû bulan istikrarsızlık ve iç karışıklık süreci değerlendirilmiştir. 1018 yılında gerçekleşecek olan Bizans seferleri, Balkanların hâkimiyeti için Bulgaristan ile Bizans arasında 200 yıl süren uzun hâkimiyet mücâdelelerinin sonu olarak görülmektedir. Bizans İmparatorluğu'nun Balkanlardaki hâmîliği resmiyet kazandıktan sonra, yeniden nüfuzunu artırmaya çalıştı̆ı faâliyetler hakkında da mâlûmat verilmiştir. Bulgaristan'daki iç karışıklığın ve İmparator II. Basileios'un halkı kaynaştırma stratejisinin yansıtılması, Bulgar Devleti'nin çöküşünün yalnızca Samuel'in ölümüyle ilişkilendirilmemesi gerektiği hususunda önemli bir göstergedir.

Son bölümde (s. 321-325) Bizans hâkimiyetine giren Bulgar tebaasının idârî, kültürel, iktisâdî ve dînî olarak imparatorluk yaşamıyla bütünleşmesi süreci ele alınmışıır. XI. yüzyıl boyunca Bizans İmparatorluğu'nun Balkanlardaki statüsü ele alınırken, Bulgarların yeniden isyana girişip, 1185'te İkinci Bulgar İmparatorluğu'nu kurma aşamasından kısaca bahsedilmiştir. Ancak yazar, her iki devletin de Balkanlar'daki hâkimiyet mücâdelesinde sahip oldukları eski güçlerini ve nüfuzlarını geri kazanamadığını vurgulayarak çalışmayı sonuca bağlamıştır. Akabinde ise yazarın çalışmada başvurduğu kaynak ve araştırma eserlerini intivâ eden bibliyografya (s. 327-348) ile eserin içinde bulunan kavramların kolay bir şekilde bulunmasına yardımcı olmak amacıyla başlık, yer ve kişi adlarının alfabetik sıralamasını içeren bir dizine (s. 349-363) yer verilmiştir.

Yazar bu çalışmada, yaklaşık 200 yıl sürecek olan Bulgar-Bizans hâkimiyet mücâdelelerinin askerî boyutunu tafsîlâtı olarak ele alırken aynı zamanda siyasî, kültürel ve diplomatik yönlerini de değerlendirmiştir. Bu hususta birincil odak noktası Bizans'tan çok Bulgarlar olmuştur. VIII. yüzyıldan XI. yüzyıla kadar olan Bulgar Devleti ile Bizans İmparatorluğu arasındaki münâsebetlerin, Bulgarların perspektifinden ele alınmış olması eseri ayrıcalıklı ve nitelikli kılmıştır. Kronolojik özenle anlatılan mücâdeleler, haritalarla tasvir edilerek okuyucuya sunulmuştur. Çeşitli kaynaklarla zenginleştirilen çalışma, özellikle askerî tarih alanında araştırma yürütmek isteyenler için oldukça önem arz etmektedir. 


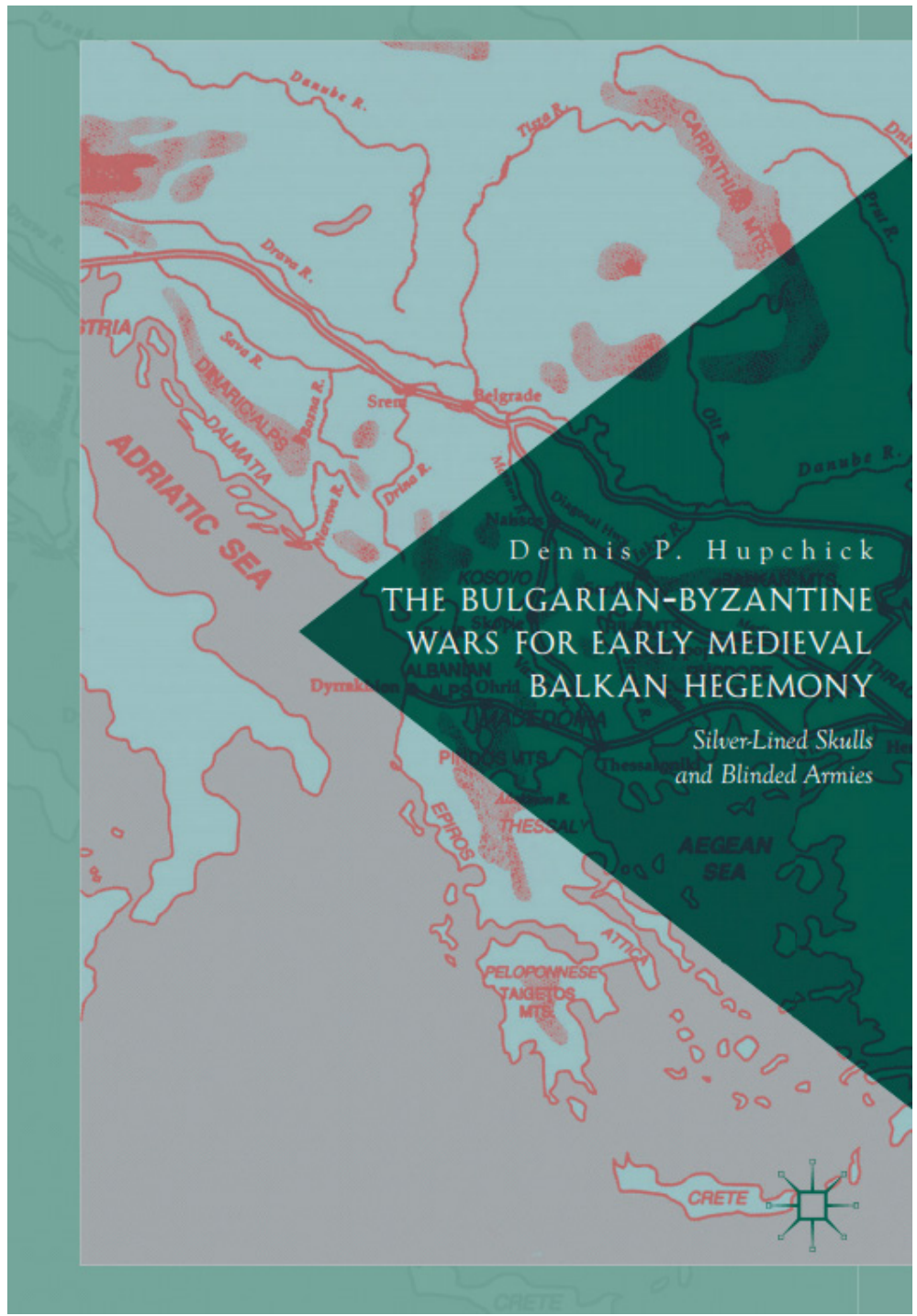

